\title{
Growth and elemental composition (C, N, P) during larval developmental stages of mass- cultured swimming crab Portunus trituberculatus
}

\author{
B. K. Lim, K. Hirayama \\ Graduate School of Marine Science and Engineering, Nagasaki University, 1-14 Bunkyo-machi, Nagasaki 852, Japan
}

\begin{abstract}
Larval rearing of the swimming crab Portunus trituberculatus for mass production was carried out from the first zoeal stage to the first crab stage. Larvae were collected during 9 rearing trials conducted either at an average water temperature of $23^{\circ} \mathrm{C}(19$ to $22 \mathrm{~d})$ or at $28^{\circ} \mathrm{C}(14$ to $15 \mathrm{~d})$. The threshold temperature for the swimming crab larvae to metamorphose was estimated at $13.4^{\circ} \mathrm{C}$. Effective cumulative water temperature (day-degrees) for the hatched larvae to molt to the zoea 2 stage was ca $43^{\circ} \mathrm{C}$; to zoea $3, \mathrm{ca} 72^{\circ} \mathrm{C}$; to zoea 4 , ca $103^{\circ} \mathrm{C}$; to megalopa, ca $144{ }^{\circ} \mathrm{C}$; and to the first crab stage, ca $199^{\circ} \mathrm{C}$. After each molt the larvae grew exponentially and exhibited a 2.4 to 2.5 times increase in fresh and dry body weights, C, N, P and energy. The water component of fresh body weight was 79 to $80 \%$ in all larval stages, and a ratio of ca $25: 5.1$ of $C: N: P$ was noted in all larval stages.
\end{abstract}

\section{INTRODUCTION}

The distribution of swimming crab Portunus trituberculatus extends from the Tsugaru Straits, between Honshu and Hokkaido of Japan, southward to Hong Kong. In Japan this species is one of the most important commercial fisheries resources. Larvae were first successfully cultured about 50 yr ago and presently are raised in various parts of Japan for restocking purposes. The production has increased steadily, and in 1988 about 48.6 million individuals of young crab were produced (Anonymous 1990).

The major chemical constituents of many crustaceans have been previously described (Childress \& Nygaard 1974, Parsons et al. 1984). With respect to decapod larvae, Dawirs (1980) analyzed the $\mathrm{C}, \mathrm{N}$ and $\mathrm{H}$ contents of all larval stages of Pagurus bernhardus and Carcinus maenas, Hirota \& Fukuda (1985) measured the elemental composition of larvae of a pelagic brachyuran crab species, and Anger (1988) conducted similar studies on Inachus dorsettensis larvae. Knowledge of these components allows one to estimate the biomass and production of larvae in pelagic ecosystems of adjacent waters.

We previously analyzed the nitrogen and phosphorus contents of swimming crab larvae as part of a nutrient budget calculation in the larval rearing tanks
(Lim \& Hirayama 1990). Although the swimming crab has been extensively studied with respect to, e.g., larval production techniques (Kurata 1983), oxygen consumption (Tamanoi et al. 1979, Morioka et al. 1988), metamorphosis of internal organs during the proecdysial period (Hamazaki 1989) and developmental processes of internal organs during metamorphosis in the larval periods (Nakamura 1990), its growth patterns and chemical constituents are still largely unknown.

The present study describes larval growth of masscultured swimming crabs from the first zoeal stage to the first crab stage by measuring fresh and dry body weights, and by analyzing the carbon, nitrogen and phosphorus content. The threshold temperature for development and thermal constant of the larvae, and effective cumulative water temperatures (day-degrees) for molting to each larval stage, were also determined.

\section{MATERIALS AND METHODS}

Handling of larvae. Egg-carrying crabs were dredged from the Sea of Ariake adjacent to Shimabara. Each egg-laden crab was placed into a black polycarbonate tank $\left(1 \mathrm{~m}^{3}\right)$ and allowed to spawn overnight. The hatched larvae were transferred into a rearing tank, and cultivated through the 4 zoeal stages $\left(Z_{1}\right.$ to 
$Z_{4}$ ), the megalopal stage $(M)$, and to the first crab stage $\left(C_{1}\right)$. The routine feeding regimen consisted of rotifers for $Z_{1}, Z_{2}$ and $Z_{3}$, followed by nauplii of brine shrimp for $Z_{4}$ and $M_{1}$ and minced clam, minced shrimp and artificial diets (Kyowa Hakko Kogyo Co., Ltd.) for $M$ and $\mathrm{C}_{1}$. Phytoplankton, chlorella (Nannochloropsis sp.), diatoms (Chaetoceros sp.), and chemical fertilizers were also introduced into the tanks. The larval rearing was conducted at the Saga Prefectural Sea Farming Center during June and July in 1986 and 1987, and at the Nagasaki City Aquacultural Center during July and August in 1988 and 1989. In Saga a circular $100 \mathrm{~m}^{3}$ tank was used, while in Nagasaki a rectangular $70 \mathrm{~m}^{3}$ tank was employed.

Sampling of larvae. Larval growth was studied during 9 trials: 1 in 1986, 3 in 1987, 2 in 1988, and 3 in 1989. Almost all of the larvae for each trial were obtained from a single brood crab. The larvae were collected with a plankton net every morning during the rearing period. They were placed on filter paper to absorb the surficial water before measuring their fresh body weight with an electronic balance. At each sampling, ca $100 \mathrm{mg}$ of larvae (total fresh body weight) were collected. To measure dry body weight and chemical constituents, the larvae were wrapped in a sheet of aluminum foil, placed into a $20 \mathrm{ml}$ vial containing silica gel, and stored at $-20^{\circ} \mathrm{C}$ for $3 \mathrm{mo}$. The silica gel was replaced several times during this period. Dry body weight measurements were repeated until a constant weight was obtained.

Observation of larval rearing. In order to distinguish among the larval stages, a portion of the sampled larvae were individually observed either with a microscope or with the naked eye throughout the rearing period. The staging differentiation was based on criteria established by Kurata (1983). Since the larvae in each trial normally molted simultaneously overnight, almost all individuals were at the same stage. In exceptional cases, the larvae were considered to be in a new stage if more than $80 \%$ of the observed larvae had molted. Water temperature was measured twice a day, in the morning and in the afternoon, and was averaged to yield the daily mean water temperature. The threshold temperature for development and the thermal constant were calculated using the theory of heat summation known as Réaumur's law (Murai \& Ito 1977). The effective cumulative water temperature (day-degrees) was calculated by summing the daily differences between daily mean water temperature and the threshold temperature for development. One day-degree refers to a mean water temperature 1 degree above the threshold temperature for development, lasting for $1 \mathrm{~d}$. The threshold temperature is the lowest temperature at which development through a given stage can be completed. The needed summation of heat up to a selected end point is called the thermal constant for that set of processes.

Elemental analyses. Analysis of carbon, nitrogen and phosphorus was conducted on dried larvae. The carbon and nitrogen content was analyzed with a $\mathrm{C}-\mathrm{N}$ corder (Yanagimoto MT-500). Phosphorus content was determined by hydrolyzing the samples to polyphosphate and orthophosphate with hydrochloric acid after drying and baking (Solórzano \& Sharp 1980), and then applying the molybdate method using a spectrophotometer (Hitachi 150-20). Chemical analysis was not performed in 1986. Energy of the larvae was calculated from the $\mathrm{N}$-corrected formula given in Salonen et al. (1976)

\section{RESULTS}

\section{Larval production and growth}

Table 1 presents the cumulative data from the 9 larval rearing trials. The larvae took ca 14 to $22 \mathrm{~d}$ to develop from the first zoeal stage to the first crab stage. These larvae can be roughly divided into 2 groups, based on mean water temperature: those reared at $23^{\circ} \mathrm{C}$ (Trial nos. 1 to 4 ), and those at $28^{\circ} \mathrm{C}$ (Trial nos. 5 to 9 ). There was an obvious difference in the survival rate among these trials, ranging from 0.9 to $48.3 \%$. Even in the rearing tank with the lowest survival rate (Trial 5), more than $10^{4} \mathrm{C}_{1}$ individuals were harvested. Salinity in these trials fluctuated between 31 and 35 ppt during the rearing period. Other data regarding the larval production and parameters of water quality have been previously reported (see Lim \& Hirayama 1990).

Fig. 1 shows the typical larval growth $\left(Z_{1}\right.$ to $\left.C_{1}\right)$ measured (as fresh body weight) in 2 rearing trials (Trials 4 and 7 ), which were conducted at 2 different water temperatures. The growth rate observed in each trial is expressed as an equation, shown in Table 1 . The larvae in Trials 1 to 4 , which were reared at the lower water temperature, had a longer rearing period, and also exhibited a lower growth rate (slope b). These equations were used to compare larval growth between rearing trials. Ordinarily, the hatched larvae did not grow linearly. Larval growth can be expressed as a 'stepped function', that is, after molting the larvae gained weight exponentially, but displayed almost no weight gain during each larval stage (Fig. 1). The duration of each stage of larvae reared at $23^{\circ} \mathrm{C}$ was $3 \mathrm{~d}$ for $Z_{1}$ and $Z_{2}, 3$ to $4 \mathrm{~d}$ for $Z_{3}, 4$ to $5 \mathrm{~d}$ for $Z_{4}$, and 5 to $7 \mathrm{~d}$ for $M$. At $28^{\circ} \mathrm{C}$, the larvae required $2 \mathrm{~d}$ each for $Z_{1}, Z_{2}$ and $Z_{3}, 3 \mathrm{~d}$ for $Z_{4}$, and $4 \mathrm{~d}$ for $M$. The larvae achieved $C_{1} 19$ to $20 \mathrm{~d}$ after hatching at $23^{\circ} \mathrm{C}$, and $14 \mathrm{~d}$ at $28^{\circ} \mathrm{C}$.

The thermal constant $(K)$ and threshold temperature for development $(t)$ to the first crab stage were calcu- 
Table 1. Portunus trituberculatus. Data from the 9 larval rearing trials. Trials 1 to 4 were conducted at the Saga Prefectural Sea Farming Center with a $100 \mathrm{~m}^{3}$ tank, Trials 5 to 9 at the Nagasaki City Aquacultural Center with a $70 \mathrm{~m}^{3}$ tank. Y $Y$ fresh body weight ( $\mu$ g ind. ${ }^{-1}$ ); $X=$ no. of days after hatching

\begin{tabular}{|c|c|c|c|c|c|c|c|}
\hline $\begin{array}{l}\text { Year, } \\
\text { Trial } \mathrm{r}\end{array}$ & & $\begin{array}{l}\text { Rearing } \\
\text { period } \\
\text { (d) }\end{array}$ & $\begin{array}{l}\text { No. of crabs } \\
\text { produced } \\
\left(\times 10^{4}\right)\end{array}$ & $\begin{array}{c}\text { Survival } \\
\text { rate } \\
(\%)\end{array}$ & $\begin{array}{c}\text { Range of water } \\
\text { temperature } \\
\left({ }^{\circ} \mathrm{C}\right)\end{array}$ & $\begin{array}{c}\text { Formula for } \\
\text { larval growth } \\
(\ln Y=\ln a+b X)\end{array}$ & $R^{2}$ \\
\hline 1986 & 1 & 19 & 84.0 & 24.1 & $23-25$ & $\ln Y=3.836+0.267 X$ & 0.982 \\
\hline 1987 & $\begin{array}{l}2 \\
3 \\
4\end{array}$ & $\begin{array}{l}21 \\
22 \\
22\end{array}$ & $\begin{array}{c}24.2 \\
107.0 \\
46.5\end{array}$ & $\begin{array}{r}7.0 \\
48.3 \\
11.6\end{array}$ & $\begin{array}{l}22-25 \\
22-25 \\
22-24\end{array}$ & $\begin{array}{l}\ln Y=3.784+0.263 X \\
\ln Y=4.111+0.239 X \\
\ln Y=4.358+0.214 X\end{array}$ & $\begin{array}{l}0.967 \\
0.974 \\
0.962\end{array}$ \\
\hline 1988 & $\begin{array}{l}5 \\
6\end{array}$ & $\begin{array}{l}15 \\
15\end{array}$ & $\begin{array}{r}1.2 \\
35.4\end{array}$ & $\begin{array}{r}0.9 \\
15.5\end{array}$ & $\begin{array}{l}27-28 \\
27-28\end{array}$ & $\begin{array}{l}\ln Y=4.237+0.347 X \\
\ln Y=4.223+0.329 X\end{array}$ & $\begin{array}{l}0.982 \\
0.965\end{array}$ \\
\hline 1989 & $\begin{array}{l}7 \\
8 \\
9\end{array}$ & $\begin{array}{l}15 \\
14 \\
14\end{array}$ & $\begin{array}{r}107.4 \\
54.0 \\
56.6\end{array}$ & $\begin{array}{l}44.0 \\
41.5 \\
34.7\end{array}$ & $\begin{array}{l}27-28 \\
27-28 \\
27-28\end{array}$ & $\begin{array}{l}\ln Y=4.147+0.335 X \\
\ln Y=4.206+0.341 X \\
\ln Y=4.149+0.332 X\end{array}$ & $\begin{array}{l}0.957 \\
0.961 \\
0.959\end{array}$ \\
\hline
\end{tabular}

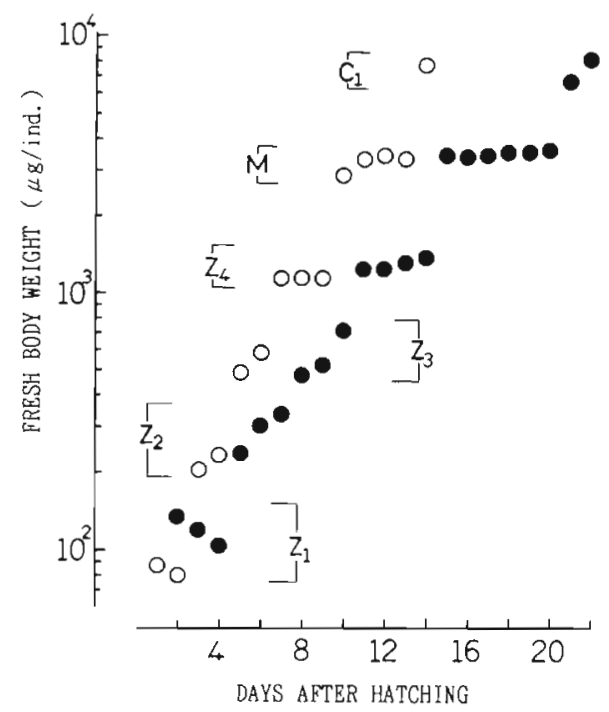

Fig. 1. Portunus trituberculatus. Typical larval growth (fresh body weight) during 2 trials from the first zoeal stage to the first crab stage. ( Trial 4 , conducted at $23^{\circ} \mathrm{C}_{\text {; }}(0)$ : Trial 7 , conducted at $28^{\circ} \mathrm{C}$. Developmental stages: $Z_{\text {, zoeali }} \mathrm{M}$, megalopal; C, crab lated from the regression equation given in Table 2. The calculated values $K$ and $t$ were $198.9^{\circ} \mathrm{C}$ and $13.4^{\circ} \mathrm{C}$, respectively. Fig. 2 shows the average effective cumulative water temperatures required for the hatched larvae to molt to each new stage. The relationship between these 2 variables can be described as hyperbolic. That is, the intervals between the effective cumulative water temperatures became larger as the larvae developed from $Z_{2}$ to $C_{1}$. The effective cumulative water temperature required for achieving each new larval stage was calculated from the following equation:

$$
1 / S=0.0742+18.3467 / T_{C} \quad\left(R^{2}=0.999\right)
$$

where $S$ is a numerical expression of each stage, for which $Z_{2}, Z_{3}, Z_{4}, M$ und $C_{1}$ equal $2,3,4,5$ and 6 , respectively, and $T_{c}=$ cumulative water temperature. The effective cumulative water temperatures required for the hatched larvae to molt to $Z_{2}, Z_{3}, Z_{4}, M$ and $C_{1}$ were $\mathrm{Ca} 43,72,103,144$ and $199^{\circ} \mathrm{C}$, respectively.

A linear relationship between fresh body weight and dry body weight was noted (Fig. 3). The slope was ca 1;

Table 2. Portunus trituberculatus. Calculation of the thermal constant $(K)$ and the threshold temperature for development $(t)$ of larvae. Mean water temperature $(T)$ is the average daily water temperature during the period for reaching the first $\mathrm{crab}$ stage $\left(\mathrm{C}_{1}\right)$; $D=$ period for reaching $C_{1} ; V=$ velocity of development

\begin{tabular}{|c|c|c|c|c|c|c|c|c|c|}
\hline Variable & 1 & 2 & 3 & 4 & $\begin{array}{c}\text { Trial no. } \\
5\end{array}$ & 6 & 7 & 8 & 9 \\
\hline$T\left({ }^{\circ} \mathrm{C}\right)$ & 23.70 & 23.15 & 23.38 & 23.18 & 27.57 & 27.61 & 27.87 & 27.48 & 27.44 \\
\hline$D(\mathrm{~d})$ & 19 & 20 & 20 & 21 & 14 & 14 & 14 & 14 & 14 \\
\hline$V(1 / D)$ & 0.053 & 0.050 & 0.050 & 0.048 & 0.071 & 0.071 & 0.071 & 0.071 & 0.071 \\
\hline \multicolumn{6}{|c|}{$\begin{array}{l}\text { Regression between mean water temperature and velocity development: } \\
\text { Calculation of thermal constant: } \\
\text { Calculation of threshold temperature for development: }\end{array}$} & \multicolumn{4}{|c|}{$\begin{array}{l}V=a+b T=-0.0674+0.00503 T\left(\mathrm{R}^{2}=0.993\right) \\
K=1 / b=198.9^{\circ} \mathrm{C} \\
V=0, t=|a| /|b|=0.0674 / 0.00503=13.4^{\circ} \mathrm{C}\end{array}$} \\
\hline
\end{tabular}




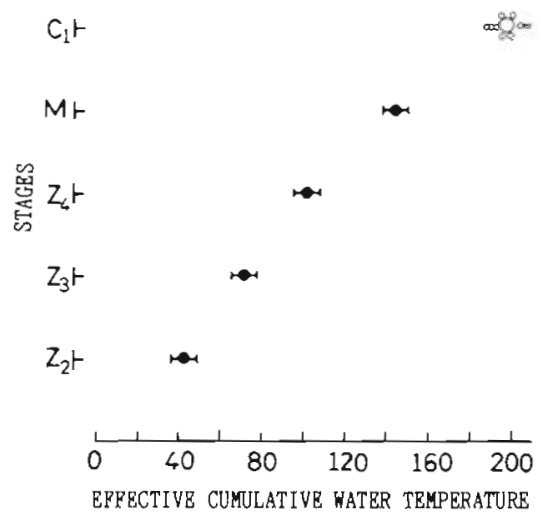

Fig. 2. Portunus trituberculatus. Effective cumulative water temperatures (day-degrees) required for achieving the molting stages. Filled circles represent arithmetic means; the larger open circle represents the thermal constant, and the 9 smaller open circles represent the daily effective cumulative temperatures up to the first crab stage in the 9 trials

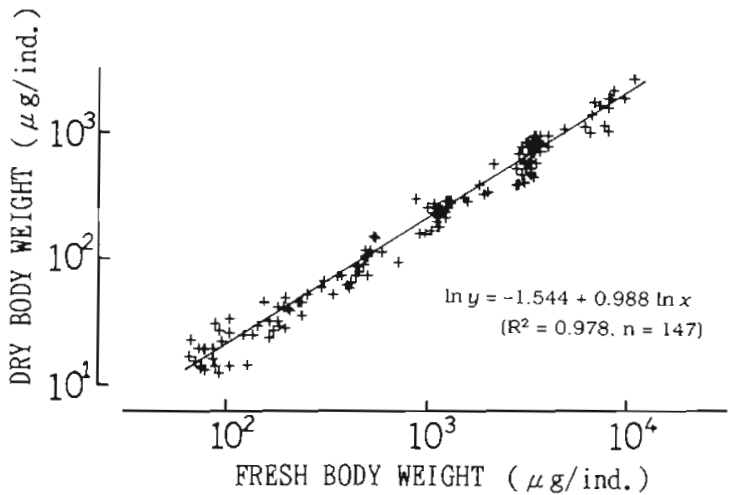

Fig. 3. Portunus trituberculatus. Linear relationship between fresh body weight and dry body weight from the first zoeal stage to the first crab stage in the 9 trials

thus there was a proportional relationship between these 2 variables. Linear regressions for fresh body weight vs 3 chemical constituents $(C, N, P)$ were also determined (Fig. 4). The slope of these linear regressions was also ca 1

Body weights, chemical constituents, and energy of each larval stage

Arithmetic means and standard deviations for body weights, chemical constituents, and energy of each larval stage were calculated from the 9 trials. The calculated data are presented in Table 3. Regression relationships between the larval stages and these variables after natural logarithmic transformation can be expressed as follows (all values in $\mu \mathrm{g}$ ind. ${ }^{-1}$, except for energy, in $\mathrm{J}$ ind.$^{-1}$ ):

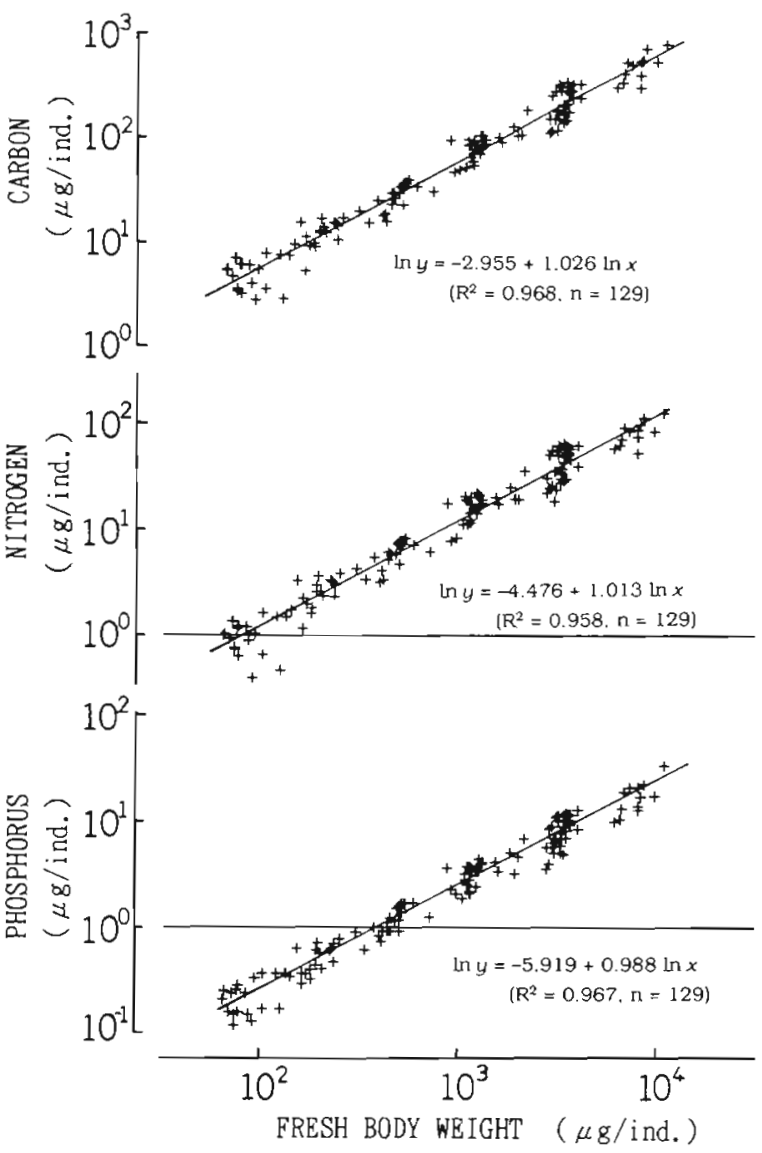

Fig. 4. Portunus trituberculatus. Linear relationships between fresh body weight and carbon, nitrogen, and phosphorus contents throughout larval development during the 9 trials

$$
\begin{array}{ll}
\text { Fresh weight: } & \ln W_{\mathrm{f}}=3.518+0.905 S\left(\mathrm{R}^{2}=0.999\right) \\
\text { Dry weight: } & \ln W_{\mathrm{d}}=1.897+0.907 S\left(\mathrm{R}^{2}=0.999\right) \\
\text { Carbon: } & \ln \mathrm{C}=0.786+0.914 S\left(\mathrm{R}^{2}=0.999\right) \\
\text { Nitrogen: } & \ln \mathrm{N}=-0.810+0.911 S\left(\mathrm{R}^{2}=0.999\right) \\
\text { Phosphorus: } & \ln \mathrm{P}=-2.299+0.879 S\left(\mathrm{R}^{2}=0.999\right) \\
\text { Energy: } & \ln E=-2.559+0.910 S\left(\mathrm{R}^{2}=0.999\right)
\end{array}
$$

where $S$ represents the larval stages, transformed into numerical values as mentioned above. After each molt there was a ca 2.4 to $2.5\left(e^{0.88}\right.$ to $\left.e^{0.91}\right)$ times increase in each of the above variables. The water component of fresh body weight was 79 to $80 \%$ in all larval stages. The average percentage of dry body weight for the 3 chemical constituents was: $34.3 \%, C_{i} 6.9 \%, N_{i}$ and $1.4 \%, P$ Ratios of $\mathrm{C}: \mathrm{N}, \mathrm{C}: \mathrm{P}$ and $\mathrm{N}: \mathrm{P}$ at all larval stages ranged from 4.6 to $5.6,23.8$ to 27.1 and 4.4 to 5.6 , respectively. The C: N : P ratio was ca $25: 5$ 1. Energy values fluctuated between 9.9 and $13.4 \mathrm{~J} \mathrm{mg}^{-1}$ dry body weight.

\section{DISCUSSION}

The larval survival rate was significantly different among these 9 rearing trials (Table 1 ), although the 
Table 3. Portunus trituberculatus. Means $\pm \mathrm{SD}$ of individual fresh body weight $\left(W_{t}\right)$, dry body weight $\left(W_{\mathrm{d}}\right)$, water content $\left(\mathrm{H}_{2} \mathrm{O}\right)$, chemical constituents (C, N, P), proportion (\%) of elements in dry body weight, ratios of the elements, and energy for each larval stage. $\mathrm{Z}$ : zoeal stage; $M$ : megalopal stage; $C$ : crab stage; n: number of replicate analyses

\begin{tabular}{|c|c|c|c|c|c|c|c|}
\hline \multirow[t]{2}{*}{ Variables } & \multicolumn{6}{|c|}{ Stages } & \multirow[t]{2}{*}{$\mathrm{n}$} \\
\hline & $\mathrm{Z}_{1}$ & $\mathrm{Z}_{2}$ & $\mathrm{Z}_{3}$ & $Z_{4}$ & M & $C_{1}$ & \\
\hline$W_{\mathrm{f}}\left(\mu \mathrm{g}\right.$ ind. $\left.{ }^{-1}\right)$ & $90.2 \pm 18.8$ & $200.3 \pm 25.3$ & $482.4 \pm 28.9$ & $1234.6 \pm 197.7$ & $3281.4 \pm 225.3$ & $7794.5 \pm 1148.4$ & 9 \\
\hline$W_{\mathrm{d}}\left(\mu \mathrm{g}\right.$ ind $\left.^{-1}\right)$ & $18.0 \pm 4.1$ & $41.2 \pm 6.9$ & $95.1 \pm 15.7$ & $240.2 \pm 31.2$ & $641.9 \pm 55.1$ & $1648.5 \pm 406.7$ & 9 \\
\hline $\mathrm{H}_{2} \mathrm{O}(\%)$ & $79.7 \pm 4.1$ & $79.4 \pm 2.7$ & $80.3 \pm 3.3$ & $80.4 \pm 1.5$ & $80.4 \pm 1.1$ & $79.0 \pm 3.4$ & 9 \\
\hline $\begin{array}{c}\mathrm{C}\left(\mu \mathrm{g} \text { ind. }^{-1}\right) \\
\left(\% W_{\mathrm{d}}\right)\end{array}$ & $\begin{array}{r}5.6 \pm 1.2 \\
33.1 \pm 8.0\end{array}$ & $\begin{array}{l}13.9 \pm 1.6 \\
34.2 \pm 6.3\end{array}$ & $\begin{array}{l}33.2 \pm 5.0 \\
37.1 \pm 9.0\end{array}$ & $\begin{array}{l}85.6 \pm 6.9 \\
35.8 \pm 2.6\end{array}$ & $\begin{array}{c}224.8 \pm 21.3 \\
35.1 \pm 2.6\end{array}$ & $\begin{array}{c}527.4 \pm 140.2 \\
30.5 \pm 2.3\end{array}$ & $\begin{array}{l}8 \\
8\end{array}$ \\
\hline $\begin{array}{r}N\left(\mu g \text { ind }^{-1}\right) \\
\left(\% W_{\mathrm{d}}\right)\end{array}$ & $\begin{array}{l}1.0 \pm 0.2 \\
6.2 \pm 1.2\end{array}$ & $\begin{array}{l}2.9 \pm 0.3 \\
7.1 \pm 1.2\end{array}$ & $\begin{array}{l}6.7 \pm 0.5 \\
7.5 \pm 1.3\end{array}$ & $\begin{array}{r}18.7 \pm 2.0 \\
7.9 \pm 1.4\end{array}$ & $\begin{array}{r}47.4 \pm 6.9 \\
7.4 \pm 1.0\end{array}$ & $\begin{array}{c}93.5 \pm 20.4 \\
5.5 \pm 0.3\end{array}$ & $\begin{array}{l}8 \\
8\end{array}$ \\
\hline $\begin{array}{l}P\left(\mu g \text { ind }^{-1}\right) \\
\left(\% W_{d}\right)\end{array}$ & $\begin{array}{l}0.24 \pm 0.05 \\
1.43 \pm 0.33\end{array}$ & $\begin{array}{l}0.61 \pm 0.13 \\
1.52 \pm 0.43\end{array}$ & $\begin{array}{l}1.40 \pm 0.30 \\
1.57 \pm 0.45\end{array}$ & $\begin{array}{l}3.36 \pm 0.42 \\
1.40 \pm 0.14\end{array}$ & $\begin{array}{l}8.63 \pm 0.72 \\
1.35 \pm 0.04\end{array}$ & $\begin{array}{r}19.68 \pm 5.24 \\
1.14 \pm 0.14\end{array}$ & $\begin{array}{l}8 \\
8\end{array}$ \\
\hline$C: N$ & $5.4 \pm 0.7$ & $4.8 \pm 0.3$ & $5.0 \pm 0.4$ & $4.6 \pm 0.5$ & $4.8 \pm 0.5$ & $5.6 \pm 0.4$ & 8 \\
\hline $\mathrm{C}: \mathrm{P}$ & $23.8 \pm 6.9$ & $23.2 \pm 3.5$ & $24.0 \pm 2.0$ & $25.7 \pm 2.1$ & $26.1 \pm 1.8$ & $27.1 \pm 2.8$ & 8 \\
\hline$N: P$ & $4.4 \pm 0.9$ & $4.8 \pm 0.9$ & $4.9 \pm 0.8$ & $5.6 \pm 0.8$ & $5.5 \pm 0.7$ & $4.9 \pm 0.7$ & 8 \\
\hline $\mathrm{J}$ ind. $^{-1}$ & $0.19 \pm 0.06$ & $0.47 \pm 0.08$ & $1.19 \pm 0.31$ & $2.97 \pm 0.18$ & $7.76 \pm 0.88$ & $17.24 \pm 4.95$ & 8 \\
\hline $\mathrm{J} \mathrm{mg}^{-1}$ & $11.4 \pm 4.1$ & $11.9 \pm 3.2$ & $13.4 \pm 5.0$ & $12.5 \pm 1.3$ & $12.1 \pm 1.3$ & $9.9 \pm 1.0$ & 8 \\
\hline
\end{tabular}

routine feeding procedures were similar. The lower survival rates in Trials 2 and 5 were attributed to the mass mortality that occurred during molting to the megalopal stage. This period is termed the critical period' of swimming crab larval development. This phenomenon also occurs during larval development of other decapod species (Hartnoll \& Mohamedeen 1987. Sulkin \& McKeen 1989, Mene et al. 1991). Ammonia and nitrite levels in the water during the trials fluctuated below the larval resistance limit reported by Mawatari \& Hirayama (1975). In addition, detrimental handling of the brood crabs could not be identified as a cause of mass mortality when larval vitality during starvation experiments was tested among the hatched larvae from 6 individual brood crabs (unpubl. data). Nevertheless, the larvae in the present study did not significantly differ among trials with respect to their weights and chemical constituents at each larval stage, and thus they can be expressed by regression equations with an $\mathrm{R}^{2}$ value (coefficient of determination) of more than $95 \%$. Once the larvae molt, they gain a constant exponential increment at each larval stage.

Water temperature was the only obvious environmental factor which varied among these trials. The period of larval development was shorter at a higher rearing water temperature (Fig. 1). The larvae of Macrobrachium rosenbergii (Gomez Diaz 1987), Cancer magister (Sulkin \& McKeen 1989) and Necora puber (Mene et al. 1991) also have shorter periods of early larval development at higher water temperatures. Figs. $1 \& 2$ suggest that larval stage durations become longer as larvae develop from $Z_{1}$ to $C_{1}$. This phenomenon has also been found in other decapod species: Hyas araneus (Anger 1983) and Inachus dorsettensis (Anger 1988).

Harding et al. (1983) noted that larval hatching of Homarus americanus usually begins only after water temperatures rise above $12.5^{\circ} \mathrm{C}$, and that the larvae require even warmer water to complete development. A number of mathematical formulae have been used in an attempt to express the relationship between temperature and the velocity of biological processes in many organisms. Réaumur's law is such an equation (Murai \& Ito 1977). Since molt staging of the swimming crab larvae was significantly related to the effective water temperature, it is thought that the relationship holds not only for cultured populations, but also for those in coastal waters.

The larval stages of the swimming crab exhibited exponential growth after each molting, as mentioned above. This is similar to the larval growth of Pagurus bernhardus in zoeal stages, but the megalopal larvae of this species does not metamorphose exponentially to the first crab stage (Anger 1989), whereas the megalopal larvae of the swimming crab does. The described pattern of growth differs from that found in Carcinus maenas (Dawirs 1983), Hyas coarctatus (Jacobi \& Anger 1985), H. araneus (Anger \& Jacobi 1985) and Inachus dorsettensis (Anger 1988). These species seem to have no exponential growth after molting. The variation may be due to species and habitat differences. The dry body weight of swimming crab larvae was also measured at the megalopal stage by Hirota \& Fukuda (1985) and at all larval stages by 
Morioka et al. (1988). The number of specimens measured by these authors was much smaller than in our study. In spite of the small numbers and the fact that these authors used a different drying method, the body weights reported are almost identical. The range of values for water content and percentages of chemical constituents relative to dry body weight in all larvai stages of swimming crab generally approximate those of all the zooplankton groups analyzed by Curl (1962), Beers (1966) and Omori (1969). The phosphorus contents (\% of dry body weight) of many groups of zooplankton (0.1 to $1.2 \%$ ) are comparatively smaller than those of swimming crab larvae. Omori (1969) also calculated the $\mathrm{C}: \mathrm{N}$ ratio of various zooplankton samples; they ranged from 3 to 8 . The $C: N$ ratios of the swimming crab at all larval stages were also distributed within this range (Table 3 ). The $\mathrm{C} \cdot \mathrm{N}$ ratio is considered an indicator of the lipid.protein ratio, and has been reported to decline under starvation (Ikeda 1974, Sekiguchi 1975). However, the pattern of daily fluctuations in the ratios varied considerably among the trials; the conspicuous cyclical changes which have been described in I. dorsettensis larvae (Anger 1988) were not detected.

The swimming crab larvae were reared using the 'community culture method' on a large scale. Thus, it could be said that these hatched larvae grew and metamorphosed to the first crab stage under 'seminatural conditions', despite the fact that the system was closed. Consequently, the findings under these conditions can be considered an adequate description of the growth pattern and biochemical changes of swimming crab larvae during their ordinary development.

Acknowledgements. We are very grateful to the staff of the Saga Prefectural Sea Farming and Nagasaki City Aquacultural Centers who cooperated with this study. We also thank Dr T Senta and Mr M. Pawluk for reviewing our manuscript.

\section{LITERATURE CITED}

Anger, K. (1983). Temperature and the larval development of Hyas araneus L. (Decapoda: Majidae); extrapolation of laboratory data to field conditions. J. exp. mar. Biol. Ecol. 69: 203-215

Anger, K. (1988). Growth and elemental composition (C, N, H) in Inachus dorsettensis (Decapoda: Majidae) larvae reared in the laboratory. Mar. Biol. 99: 255-260

Anger, K. (1989). Growth and exuval loss during larval and early juvenile development of the hermit crab Pagurus bernhardus reared in the laboratory. Mar Biol. 103: 503-511

Anger, K., Jacobi. C. C. (1985). Respiration and growth of Hyas araneus L. larvae (Decapoda: Majıdae) from hatching to metamorphosis. J. exp. mar Biol. Ecol. 88: 257-270

Anonymous (1990). National records of larval production, larval obtaining and restocking in 1988. Fisherles Agency, Japan Sea Farming Fisheries Association, Tokyo (in Japanese)
Beers, J. R. (1966). Studies on the chemical composition of major zooplankton groups in the Sargasso Sea off Bermuda. Limnol. Oceanogr. 11 520-528

Childress, J. J., Nygaard, M. (1974). Chemical composition and buoyancy of midwater crustaceans as function of depth of occurrence off southern California. Mar. Biol. 27 $225-238$

Curl, H. (1962). Standing crops of carbon, nitrogen and phosphorus and transfer between trophic levels, in continental shelf waters south of New York. Rapp. P.-v. Réun. Cons. int. Explor. Mer 153: 183-189

Dawirs, R. R. (1980). Elemental composition (C, N, H) in larval and crab-1 stages of Pagurus bernhardus (Decapoda: Paguridae) and Carcinus maenas (Decapoda: Portunidae) Mar. Biol. 57: 17-23

Dawirs. R. R. (1983). Respiration, energy balance and development during growth and starvation of Carcinus maenas $\mathrm{L}$. larvae (Decapoda: Portunidae). J. exp. mar. Biol. Ecol. 69: 203-215

Gomez Diaz, G. (1987). Effect of environmental embryonic temperature on larval development of Macrobrachium rosenbergii (De Man). J. exp. mar. Biol. Ecol. 114: 39-47

Hamazaki, K. (1989). Metamorphosing in metabolısm organs of the proecdysial larvae of the swimming crab Portunus trituberculatus. Saibaigiken 17:87-91 (in Japanese)

Harding, G. C., Drinkwater, K. F., Vass, W P. (1983). Factors influencing the size of American lobster (Homarus americanus) stocks along the Atlantic coast of Nova Scotia, Gulf of St. Lawrence, and Gulf of Maine: a new synthesis. Can. J. Fish. Aquat. Sci. 40: 168-184

Hartnoll, R. G., Mohamedeen, H. (1987). Laboratory growth of the larvae of six British crabs. J. exp. Mar Biol. Ecol. 107: $155-170$

Hirota, R. Fukuda, Y (1985). Dry weight and chemical composition of the larval forms of crabs (Decapoda: Brachyura). Bull. Plankton Soc. Japan 32: 149-153

Ikeda, T (1974). Nutritional ecology of marine zooplankton. Mem. Fac. Fish. Hokkaido Univ. 22: 1-97

Jacobi, C. C., Anger, K. (1985). Growth and respiration during the larval development of Hyas coarctatus (Decapoda: Majidae). Mar Biol. 87 173-180

Kurata, $H$. (ed.) (1983). Techniques of mass production of the blue crab Portunus trituberculatus seedling. Larval production workshop of the blue crab. Fisheries Propagation and Aquaculture, Vol. 32. Japan Fisheries Resource Conservation Association, Tokyo (in Japanese)

Lim, B. K., Hirayama, K. (1990). Nitrogen and phosphorus budgets in larval rearing tanks for mass production of swimming crab Portunus trituberculatus. In: Hirano, R. Hanyu, I. (eds.) Proceedings of the Second Asian Fisheries Forum, Tokyo, Japan, 17-22 April 1989. The Asian Fisheries Society, Manula, p. 177-180

Mawatari, K., Hirayama, K. (1975). Studies on resistibility of some marine animals at various larval stages to ammonia, nitrite and nitrate (m Japanese). Bull. Fac. Fish. Nagasaki Univ. 39: 1-6

Mene, L., Alvarez-Ossorio, M. T., González-Gurriarán, E., Valdés, L. (1991). Effects of temperature and salunity on larval development of Necora puber (Brachyura: Portunidae). Mar. Biol. 108: 73-81

Morioka, Y, Kitajima, C., Hayashida, G. (1988). Oxygen consumption, growth and calculated food requirement of the swimming crab Portunus trituberculatus in its early developmental stage. Bull. Jap. Soc. Sci. Fish. 54: 1137-1141

Murai, M., Ito, Y. (eds.) (1977). Study on animal ecology issues 2. Kokin Shoin, Tokyo, p. 445-450 (in Japanese)

Nakamura, K. (1990). Organogenesis during metamorphosis 
in the swimming crab Portunus trituberculatus. Bull. Jap. Soc. Sci. Fish. 56: 1561-1564

Omori, M. (1969). Weight and chemical composition of some important oreanic zooplankton in the North Pacific Ocean. Mar Biol. 3: 4-10

Parsons, T R.. Takahashi, M., Hargrave, B. (eds.) (1984). Biological oceanographic processes, 3rd edn. Pergamon Press, New York, p. 50-54

Salonen, K., Sarvala, J., Hakala, I., Vilianen, M.-L. (1976). The relation of energy and organic carbon in aquatic invertebrates. Limnol. Oceanogr. 21: 724-730

Sekiguchi, H. (1975). The survival of larval fishes. Kaiyo

This article was submitted to the editor
Kagaku (Marine Sciences), Vol. 7(12). Symposium - 73, Studies on fish population 7: 36-41 (in Japanese)

Solórzano, L., Sharp, J. H. (1980). Determination of total dissolved phosphorus and particulate phosphorus in natural waters. Limnol. Oceanogr. 25: 754-758

Sulkin, S. D., McKeen, G. L. (1989). Laboratory study of survival and duration of individual zoeal stages as a function of temperature in the brachyuran crab Cancer magister. Mar. Biol. 103: 31-37

Tamanoi, S., Hirayama, K., Oka, M. (1979). Respiration rate of larvae of the swimming crab Portunus trituberculatus. Bull. Fac. Fish. Nagasaki Univ. 47. 21-26 (in Japanese)

Manuscript first received: May 15, 1991

Revised version accepted: October 16, 1991 